\title{
Effect of concentrate supplementation on performances of Ethiopian lowland afar and blackhead Ogaden lambs
}

\author{
Getahun Kebede Yadete \\ Department of Livestock Research, Debre Zeit Agricultural Research Center, Debre Zeit, Ethiopia \\ Email address: \\ getkeb2000@yahoo.com
}

To cite this article:

Getahun Kebede Yadete. Effect of Concentrate Supplementation on Performances of Ethiopian Lowland Afar and Blackhead Ogaden Lambs. Animal and Veterinary Sciences. Vol. 2, No. 2, 2014, pp. 36-41. doi: 10.11648/j.avs.20140202.14

\begin{abstract}
The study was conducted to evaluate the effect of increased concentrate supplementation on nutrient intake, growth performance, carcass characteristics, duration of feeding and profitability of Ethiopian Afar and Blackhead Ogaden (BHO) lambs. Forty-eight lambs (24/breed) initially weighing $17.84 \pm 1.6 \mathrm{~kg}$ were randomly assigned to three dietary treatments $(\mathrm{T})$ in Complete Randomized Design. Each lamb was fed on tef straw ad libtium and supplemented with 150 , $300,450 \mathrm{~g} \mathrm{~d}^{-1}$ of concentrate (containing 19.4\% crude protein (CP) and $11.28 \mathrm{MJ} \mathrm{ME} \mathrm{kg}{ }^{-1} \mathrm{DM}$ ) in T1, T2 and T3, respectively. Intake and growth trial lasted for 126 days, followed by digestibility trial of 7 days. Dry matter (DM) intake increased $(p<0.0001)$ with increasing concentrate offer in lambs in general, but higher $(p<0.05)$ in Afar than in BHO lambs. Intake of $\mathrm{CP}$ peaked at the highest level of supplementation. Increased $(\mathrm{p}<0.0001)$ digestibility of $\mathrm{DM}, \mathrm{CP}$, neutral detergent fiber (NDF) and acid detergent fiber (ADF) were noted at higher concentrate offer in Afar lambs. Average daily gain of lambs increased $(\mathrm{p}<0.0001)$ with increased concentrate, and lambs reached the target weight $(25-30 \mathrm{~kg})$ for export market relatively within short period of feeding at higher than lower level of concentrate supplementation. Given equal level of concentrate, Afar lambs reached the target weight in less days of feeding than BHO lambs. Increasing concentrate has resulted in increased slaughter weight (SW), hot carcass weight $(\mathrm{HCW})$, dressing percent (DP) and lean-to-fat ratio (LFR) in Afar lambs, while it improved SW, HCW and DP in BHO lambs. This study indicated that increased meat production measured in terms of live weight change and carcass yield in Afar and BHO lambs can be achieved at high concentrate supplementation with profit.
\end{abstract}

Keywords: Concentrate, Intake, Lambs, Live Weight, Tef Straw

\section{Introduction}

Although there exist 25.97 million sheep population in Ethiopia [1] the production and productivity is very low [2], as expressed by annual population growth rate of $1 \%$ and off-take rate of $35 \%$. The average daily growth rate of indigenous meat sheep is $50 \mathrm{~g}$, while the average carcass yield is $10 \mathrm{~kg}$ per animal.

The low performance of local sheep in terms of live weight (BW) gain and carcass yield is mainly due to inadequate nutrition [3] associated with reliance on sole natural pasture, crop residues and/or stubble grazing, which are inherently low in nutrients available being subjected to great seasonal variations[4]. Temporally abundance of forage during short rainy season is followed by long dry periods with feed deficit leading to a cycle of live weight gain and loss of animals. Thus, sheep often takes longer period to attain market weight, lowering its production efficiency. The present export market (to the Middle East countries) for Ethiopian live sheep and mutton is demanding animals of low land origin, weighing between 25 and $30 \mathrm{~kg}$ at yearling age. However, most local lambs slaughtered at this age weigh 18 to $20 \mathrm{~kg}$ [5]. Thus, lack of consistent supply of the required animals at younger age has remained a major challenge for mutton and live sheep exporters. Therefore, this study was aimed to evaluate the effect of increased concentrate supplementation on nutrient intake, growth performance, carcass characteristics, duration of feeding and economic benefit of yearling Afar and BHO lambs.

\section{Materials and Methods}

\subsection{Study Site}

This experiment was conducted on sheep research station of Debre Zeit Agricultural Research Center, Ethiopia, located at $45 \mathrm{~km}$ South East of Addis Ababa, at an altitude of 1900 meter 
above sea level (between $8.44^{\circ} \mathrm{N}$ latitude and $39.02^{\circ} \mathrm{E}$ longitude). The average maximum and minimum temperature and annual rainfall of the research station were $24.3^{\circ} \mathrm{C}, 8.9^{\circ} \mathrm{C}$ and $851 \mathrm{~mm}$, respectively.

\subsection{Animals and Feeding Management}

Forty-eight yearling male Afar and Blackhead Ogaden lambs (24/breed) were purchased from local market. All animals were ear-tagged, vaccinated against Sheep pox, Anthrax and Ovine pasteurellosis and treated against ectoand endo-parasites. After adaptation period of 15 days to the environment, pen management and diets, animals of the respective breed (overall mean live weight $=17.84 \pm 1.6 \mathrm{~kg}$ ) were randomly allotted to three dietary treatments (8 lambs per treatment), in Complete Randomized design. All animals were individually penned and fed tef straw ad libitum and daily supplemented with $150 \mathrm{~g}$ (T1), $300 \mathrm{~g}$ (T2) and $450 \mathrm{~g}$ (T3) of concentrate, twice daily at 9:00 and 2:00. The concentrate mix, on DM base, was composed of $29 \%$ wheat bran, $14 \%$ wheat middling, $7 \%$ maize grain, $49 \%$ noug seed (Guizotia abyssinica)cake and 1\% common salt, containing $19.4 \% \mathrm{CP}$ and $11.28 \mathrm{MJ} \mathrm{ME} \mathrm{kg}{ }^{-1} \mathrm{DM}$. Clean water was freely available for each animal.

Table 1. Chemical composition of experimental feed ingredients $\left(g \mathrm{~kg}^{-1} \mathrm{DM}\right)$

\begin{tabular}{lllllll}
\hline & DM & CP & ASH & NDF & ADF & ADL \\
\hline Tef straw & 927 & 44 & 109 & 777 & 449 & 50 \\
Maize grain & 905 & 92 & 22 & 158 & 34 & 0.8 \\
Noug seed cake & 916 & 301 & 119 & 365 & 286 & 110 \\
Wheat bran & 915 & 140 & 48 & 463 & 95 & 0.6 \\
Wheat- middling & 899 & 155 & 50 & 445 & 94 & 21 \\
Salt & 970 & - & - & - & - & - \\
Concentrate & 906 & 190 & 85 & 375 & 194 & 80 \\
\hline
\end{tabular}

Where, DM=Dry Matter; $\mathrm{CP}=$ Crude Protein; NDF= Neutral Detergent Fiber; $\mathrm{ADF}=$ Acid Detergent Fiber; $\mathrm{ADL}=$ Acid Detergent Lignin

Intake and growth trial was undertaken for 126 days. Daily feed offered and refusal were measured and recorded for each animal to determine intake by finding the difference between amount offered and refusal. Samples of feed offered and left over were taken daily and sub-sampled every 15 days for each animal. The live weight of lambs was taken once fortnightly after 16 hour of feed deprivation. At the end of feeding trial, three animals were randomly selected per treatment and transferred to metabolic crate to undertake digestibility trial. Lambs were adapted to fecal bags tied to them for three days followed by data collection for seven days. As true for intake and growth trial, data on feed consumption was taken for each animal. The daily fecal output was measured for each animal, of which $10 \%$ was sampled and placed in deep freezer $\left(-21^{\circ} \mathrm{C}\right)$ pending chemical analysis. Besides, three animals were selected per treatment, fastened for 12 hours, weighed and slaughtered for carcass analysis. The carcass was chilled at $4^{\circ} \mathrm{C}$ for 24 hours followed by deboning it into tissue components. Data on slaughter weight, hot carcass weight, lean meat weight, fat weight and bone weight were taken for each slaughtered animal. Dressing percentage (DP) was calculated as:

$$
\mathrm{DP}=(\mathrm{HCW} / \mathrm{SW})^{*} 100 .
$$

\subsection{Sample Analysis}

Feeds and fecal samples were analyzed for Dry Matter (DM), Ash, Crude Protein (CP) using the standard procedures[6] and also Acid Detergent Fiber (ADF), Neutral Detergent Fiber (NDF) and Acid Detergent Lignin (ADL) were determined [7].

\subsection{Statistics Analysis}

Data on feed intake, live weight change, digestibility, feed conversion ratio (g DMI g ${ }^{-1}$ gain) and carcass parameters were analyzed using the General Linear Models (GLM) procedure of SAS[8] by mathematical model that included the effects of breed, diet and interaction effect of diet and breed. Data on live weight gain of an experimental lamb was computed by finding the difference of the two weighing periods and regressing it over the number of days elapsed. Whenever GLM declares significance, treatment means were separated using LSD. The model used was:

$$
Y=\mu+a_{i}+b_{j}+(a b) i j+e_{i j k}
$$

Where, $\mathrm{Y}=$ response variables (Intake, live weight change, digestibility, FCR, carcass parameters); $\mu=$ overall mean, $a_{j}=$ effect of $i^{\text {th }}$ diet, $b_{j}=$ effect of $j^{\text {th }}$ breed, $(a b) k=$ effect of interaction $a * b$ and $e_{i j k}=$ random variation

\subsection{Cost-Benefit Analysis}

Cost-benefit analysis was done to compare the relative economic importance of the diets. Cost of all variable inputs and buying and selling prices of lambs were recorded to determine the net income of production. The sale value of each finished lamb was estimated at local market bargaining price by averaging estimates of three local sheep traders, while the market values of lambs at export abattoirs were estimated based on the final live weight of lambs. Monetary values of all other variable inputs were considered at the prevailing market price.

\section{Results and Discussion}

\subsection{Nutrient Intake}

There was a significant increase $(p<0.0001)$ in total DMI of lambs, while intake of straw reduced $(\mathrm{P}<0.01)$ with increase in the concentrate level (Table 2). Total DMI intake was higher $(\mathrm{p}=0.025)$ in Afar lambs compared to BHO lambs. Previous studies [9-11] done on Ethiopian highland and lowland Afar and BHO lambs have shown increased feed DM intake as the amount of concentrate increased. It was also reported a decrease in hay intake and an increase in total 
DM and CP intake in growing Somali goats with increased amount of peanut cake and wheat bran mixture [3]. However, non-significant $(p>0.05)$ increase in DM intake with an increase in concentrate level was reported in Afar rams fed on tef straw [12], and Washera lambs fed on urea treated rice straw [13]. Contrary to the present result, decreased DMI in fat-tailed Chall lambs was noted with increased concentrate part of a ration [14]. In the present study, increased intake of dietary CP $(p<0.0001)$ was noted with increased concentrate level, while intake of NDF $(p=0.1682)$ and $\operatorname{ADF}(p=0.2882)$ reduced. This could be due to the reduction $(\mathrm{p}<0.01)$ in the straw intake inherently low in protein, but high in fiber fractions. In this study, no interaction effect $(\mathrm{p}>0.05)$ of breed and diet was observed in nutrient consumption. The increased in DM intake of lambs at higher level of concentrate could be linked to the fact that energy requirements of lambs were met. Animals consume feed mainly to satisfy their desire for energy [7] .

Table 2. Nutrient intake of experimental animals ( $g$ per lamb $d^{-1}$ )

\begin{tabular}{|c|c|c|c|c|c|c|c|c|c|}
\hline & & $\begin{array}{l}\text { DM } \\
\text { Straw } \\
\end{array}$ & Total & $\begin{array}{l}\text { CP } \\
\text { Straw } \\
\end{array}$ & Total & $\begin{array}{l}\text { NDF } \\
\text { Straw } \\
\end{array}$ & Total & $\begin{array}{l}\text { ADF } \\
\text { Straw } \\
\end{array}$ & Total \\
\hline \multirow{5}{*}{ Diet } & T1 & $466.7 \mathrm{a}$ & $602.6 c$ & $21.3 \mathrm{a}$ & $47.2 \mathrm{c}$ & $361.9 \mathrm{a}$ & 412.8 & $208.5 a$ & 234.9 \\
\hline & $\mathrm{T} 2$ & $422.3 \mathrm{ab}$ & $694.1 \mathrm{~b}$ & $18.8 \mathrm{~b}$ & $70.5 b$ & $329.5 \mathrm{ab}$ & 431.4 & $189.9 \mathrm{ab}$ & 242.7 \\
\hline & $\mathrm{T} 3$ & $383.5 b$ & $789.4 \mathrm{a}$ & $17.1 \mathrm{~b}$ & $94.2 \mathrm{a}$ & $298.8 b$ & 451.0 & $174.5 b$ & 253.2 \\
\hline & SEM & 18.03 & 18.03 & 0.8 & 0.8 & 14.49 & 14 & 8.37 & 8.08 \\
\hline & $\mathrm{T} 1$ & $486.6 \mathrm{a}$ & $622.5 c$ & $22.3 \mathrm{a}$ & $48.2 \mathrm{c}$ & $377.2 \mathrm{a}$ & $428.1 \mathrm{~b}$ & $217.0 \mathrm{a}$ & $243.4 b$ \\
\hline \multirow{3}{*}{ Afar } & $\mathrm{T} 2$ & $438.8 \mathrm{ab}$ & $710.6 b$ & $19.3 b$ & $71.0 \mathrm{~b}$ & $344.5 \mathrm{ab}$ & $446.4 \mathrm{ab}$ & $200.2 \mathrm{ab}$ & $252.9 \mathrm{ab}$ \\
\hline & $\mathrm{T} 3$ & $417.6 b$ & $824.0 \mathrm{a}$ & $18.5 b$ & $95.7 \mathrm{a}$ & $326.1 \mathrm{~b}$ & $478.5 \mathrm{a}$ & $189.4 b$ & $268.2 \mathrm{a}$ \\
\hline & SEM & 18.59 & 18.59 & 0.84 & 1.13 & 14.42 & 14.42 & 8.3 & 8.3 \\
\hline \multirow{5}{*}{$\mathrm{BHO}$} & $\mathrm{T} 1$ & $446.8 \mathrm{a}$ & $582.7 b$ & $20.3 \mathrm{a}$ & $46.2 \mathrm{c}$ & $346.6 \mathrm{a}$ & 397.7 & 199.9 & 226.3 \\
\hline & $\mathrm{T} 2$ & $405.8 \mathrm{ab}$ & $677.6 \mathrm{a}$ & $18.4 \mathrm{ab}$ & $70.0 \mathrm{~b}$ & $314.4 \mathrm{ab}$ & 416.4 & 179.6 & 232.4 \\
\hline & $\mathrm{T} 3$ & $349.4 b$ & $754.7 \mathrm{a}$ & $15.8 \mathrm{~b}$ & $92.8 \mathrm{a}$ & $271.5 b$ & 423.4 & 159.6 & 238.2 \\
\hline & SEM & 31.12 & 31.12 & 1.37 & 1.37 & 24.18 & 24.18 & 13.97 & 13.97 \\
\hline & Afar & $447.7 \mathrm{a}$ & $719.1 \mathrm{a}$ & $20.0 \mathrm{a}$ & $71.6 \mathrm{a}$ & $349.2 \mathrm{a}$ & $451.0 \mathrm{a}$ & $202.2 \mathrm{a}$ & $254.9 \mathrm{a}$ \\
\hline \multirow[t]{2}{*}{ Mean } & $\mathrm{BHO}$ & $400.7 b$ & $671.7 \mathrm{~b}$ & $18.2 \mathrm{~b}$ & $69.7 b$ & $310.8 b$ & $412.5 b$ & $179.7 \mathrm{~b}$ & $232.3 b$ \\
\hline & SEM & 14.72 & 14.72 & 0.65 & 0.65 & 11.43 & 11.43 & 6.6 & 6.6 \\
\hline \multirow{3}{*}{$\begin{array}{l}\text { Effect, } \\
\text { p-value }\end{array}$} & Diet & 0.0061 & $<.0001$ & 0.0013 & $<.0001$ & 0.0078 & 0.1682 & 0.0142 & 0.2882 \\
\hline & Breed & 0.0262 & 0.025 & 0.0453 & 0.0381 & 0.0194 & 0.0189 & 0.0178 & 0.0174 \\
\hline & Diet*Breed & 0.7737 & 0.760 & 0.7353 & 0.685 & 0.7857 & 0.779 & 0.8539 & 0.8489 \\
\hline
\end{tabular}

Means in the same column with different letters are different $(\mathrm{P}<0.05)$; SEM=standard error of mean; $\mathrm{T} 1=\mathrm{Tef}$ straw $+150 \mathrm{~g}$ per lamb $\mathrm{d}^{-1}$ concentrate; $\mathrm{T} 2=$ Tef straw $+300 \mathrm{~g}$ per lamb d ${ }^{-1}$ concentrate; $\mathrm{T} 3=$ Tef straw $+450 \mathrm{~g}$ per lamb d $\mathrm{d}^{-1}$ concentrate.

\subsection{Apparent Digestibility}

Table 3. Apparent digestibility values $\left(\mathrm{g} \mathrm{kg}^{-1} \mathrm{DM}\right)$ of nutrients in lambs fed experimental diets.

\begin{tabular}{llllll}
\hline & Treat. & DM & CP & NDF & ADF \\
\hline \multirow{4}{*}{ Diet } & T1 & $589.2 \mathrm{~b}$ & $426.3 \mathrm{c}$ & 580.5 & 507.7 \\
& T2 & $619.8 \mathrm{ab}$ & $592.6 \mathrm{~b}$ & 559.9 & 475.9 \\
& T3 & $665.2 \mathrm{a}$ & $704.3 \mathrm{a}$ & 593.9 & 515.9 \\
& SEM & 16.9 & 19.0 & 19.0 & 23.0 \\
& T1 & $537.2 \mathrm{~b}$ & $380.7 \mathrm{~b}$ & $526.1 \mathrm{~b}$ & $442.8 \mathrm{~b}$ \\
Afar & T2 & $654.5 \mathrm{a}$ & $652.6 \mathrm{a}$ & $596.7 \mathrm{ab}$ & $520.8 \mathrm{ab}$ \\
& T3 & $683.4 \mathrm{a}$ & $711.8 \mathrm{a}$ & $628.9 \mathrm{a}$ & $547.3 \mathrm{a}$ \\
& SEM & 23.0 & 22.9 & 27.9 & 33.8 \\
& T1 & 641.2 & $472.0 \mathrm{~b}$ & $634.9 \mathrm{a}$ & $572.5 \mathrm{a}$ \\
BH & T2 & 585.1 & $532.6 \mathrm{~b}$ & $523.1 \mathrm{~b}$ & $430.9 \mathrm{~b}$ \\
& T3 & 647.0 & $696.8 \mathrm{a}$ & $558.9 \mathrm{ab}$ & $484.4 \mathrm{ab}$ \\
& SEM & 24.3 & 30.3 & 27.8 & 32.8 \\
Mean & Afar & 625.1 & 581.7 & 583.9 & 503.7 \\
& BHO & 624.5 & 567.2 & 572.3 & 495.9 \\
& Diet & $*$ & $* *$ & NS & NS \\
Sig. & Breed & NS & NS & NS & NS \\
& Diet x Breed & $* *$ & $* *$ & $*$ & $*$ \\
\hline
\end{tabular}

Means in the same column with different letters are statistically different $(\mathrm{P}<0.05)$; SEM $=$ standard error of mean; Sig. $=$ significance; NS $=$ not significant $;=\mathrm{p}<0.01 ; * *=\mathrm{p}<0.001 ; * * *=\mathrm{p}<0.0001$

Table 3 presents the apparent digestibility values of nutrients. Dry matter digestibility was improved $(p<0.01)$ by
$13 \%$ (589 vs. $\left.665 \mathrm{~g} \mathrm{~kg}^{-1} \mathrm{DM}\right)$ in lambs in general, and by $27 \%$ (537vs.683 $\left.\mathrm{g} \mathrm{kg}^{-1} \mathrm{DM}\right)$ in Afar lambs, implying increased feed utilization efficiency at higher concentrate supplementation. Similarly, the digestibility values of $\mathrm{CP}$, NDF and ADF were increased significantly $(p<0.001)$ with increased concentrate in Afar lambs. Earlier studies [12] on Afar lambs fed tef straw at various concentrate level (150$350 \mathrm{~g}$ per lamb $\mathrm{d}^{-1}$ ) has shown comparable DM digestibility (670-680 $\left.\mathrm{g} \mathrm{kg}^{-1} \mathrm{DM}\right)$, but higher in digestibility of CP (720$\left.830 \mathrm{~g} \mathrm{~kg}^{-1} \mathrm{DM}\right)$, NDF (610-680 $\left.\mathrm{g} \mathrm{kg}^{-1} \mathrm{DM}\right)$ and ADF (560$650 \mathrm{~g} \mathrm{~kg}^{-1} \mathrm{DM}$ ) than the present results. Moreover, there was no significant difference $(\mathrm{p}>0.05)$ between the Afar and BHO lambs in nutrient digestibility.

\subsection{Live Weight Change, Feed Conversion Ratio (FCR)}

The live weight change and FCR were indicated in Table 4. The final live weights of lambs increased $(p<0.0001)$ with increased concentrate level, and within the range of 25 to $30 \mathrm{~kg}$ currently required by export market. The ADG of lambs was highest $(\mathrm{p}<000.1)$ at the highest concentrate offer, increasing from 36.95 to $79.36 \mathrm{~g} \mathrm{~d}^{-1}$ in Afar lambs and from 33.48 to $65.19 \mathrm{~g} \mathrm{~d}^{-1}$ in black head Ogaden lambs. However, supplementation beyond $300 \mathrm{~g}$ per day for BHO lamb did not improve growth remarkably $(p>0.05)$, which may not be economical. Although non-significant $(p=0.1455)$, Afar lambs gained relatively better live weight than BHO lambs. 
Moreover, Afar lambs reached the minimum live weight in demand $(25 \mathrm{~kg})$ for export market at about 70 days of feeding compared to BHO lambs that took 112 days. Afar rams maintained on tef straw and supplemented $250 \mathrm{~g} \mathrm{~d}^{-1}$ of concentrate with $\mathrm{CP}$ and $\mathrm{ME}$ content comparable to the present diet gained $67.1 \mathrm{~g} \mathrm{~d}^{-1}$ of live weight, but reduced to $63 \mathrm{~g} \mathrm{~d}^{-1}$ at $350 \mathrm{~g} \mathrm{~d}^{-1}$ concentrate feeding [12]. Moreover, it was reported that intact Afar rams fed on urea treated tef straw supplemented with wheat bran achieved ADG of 65.6 $\mathrm{g}$ [11]. The present increase in the growth of lambs could be attributed to substantial improvement in feed DM intake, digestibility and feed conversion ratios. As shown in the growth curve (figure1), lambs appeared to approach market weight in shorter feeding period at higher than lower concentrate feeding. Feed conversion ratios increased in all lambs (pooled) $(\mathrm{p}=0.0005)$, in $\operatorname{Afar} \operatorname{lambs}(\mathrm{p}=0.0313)$ and BHO lambs $(\mathrm{p}=0.0022)$ with increased concentrate level. This study further indicated that high amount of protein and energy-rich concentrate is important to achieve better performances of Afar and $\mathrm{BHO}$ lambs.

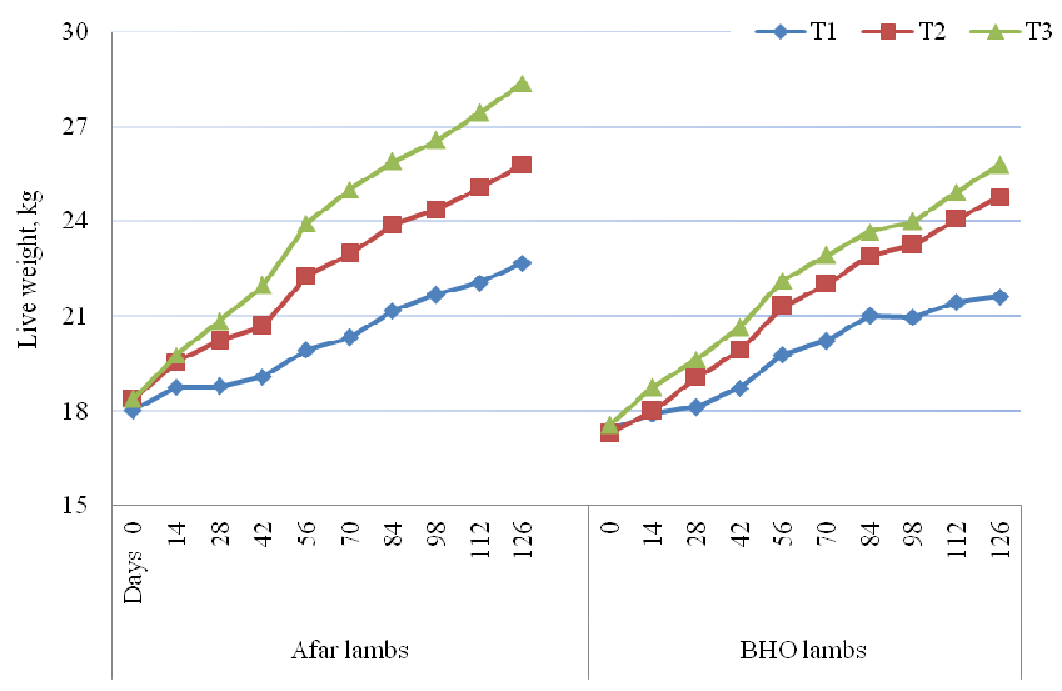

Figure 1. Trend in the liveweight of lambs during growth trial

Table 4. Live weight change and feed conversion ratios of experimental lambs

\begin{tabular}{|c|c|c|c|c|c|c|c|}
\hline & & Initial(kg) & Final(kg) & LWC(kg) & ADG(g) & $\operatorname{DMI}\left(\mathrm{g} \mathrm{d}^{-1}\right)$ & FCR(g DMI g gain) \\
\hline \multirow[t]{5}{*}{ Diet } & $\mathrm{T} 1$ & 17.71 & $22.15 \mathrm{c}$ & $4.43 \mathrm{c}$ & $35.22 \mathrm{c}$ & $602.6^{\mathrm{c}}$ & $17.11 \mathrm{~b}$ \\
\hline & $\mathrm{T} 2$ & 17.82 & $25.29 b$ & $7.46 \mathrm{~b}$ & $59.27 \mathrm{~b}$ & $694.1^{\mathrm{b}}$ & $11.71 \mathrm{a}$ \\
\hline & $\mathrm{T} 3$ & 17.97 & $27.08 \mathrm{a}$ & $9.10 \mathrm{a}$ & $72.27 \mathrm{a}$ & $789.4^{\mathrm{a}}$ & $10.92 \mathrm{a}$ \\
\hline & SEM & 0.41 & 0.51 & 0.41 & 3.29 & 18.03 & 1.7 \\
\hline & P-value & 0.9113 & $<.0001$ & $<.0001$ & $<.0001$ & $<.0001$ & 0.0005 \\
\hline \multirow[t]{5}{*}{ Afar } & $\mathrm{T} 1$ & 18.03 & $22.68 \mathrm{c}$ & $4.65 c$ & $36.95 \mathrm{c}$ & $622.5 \mathrm{c}$ & $16.85 \mathrm{~b}$ \\
\hline & $\mathrm{T} 2$ & 18.37 & $25.81 \mathrm{~b}$ & $7.43 b$ & $59.03 b$ & $710.6 \mathrm{~b}$ & $12.04 \mathrm{a}$ \\
\hline & $\mathrm{T} 3$ & 18.37 & $28.37 \mathrm{a}$ & $10.00 \mathrm{a}$ & $79.36 \mathrm{a}$ & $824.0 \mathrm{a}$ & $10.38 \mathrm{a}$ \\
\hline & SEM & 0.5 & 0.67 & 0.64 & 5.09 & 18.59 & 3.043 \\
\hline & P-value & 0.8554 & $<.0001$ & $<.0001$ & $<.0001$ & $<.0001$ & 0.0313 \\
\hline \multirow[t]{5}{*}{ BHO } & $\mathrm{T} 1$ & 17.4 & $21.62 b$ & $4.21 \mathrm{~b}$ & $33.48 b$ & $582.7 \mathrm{~b}$ & $17.40 \mathrm{~b}$ \\
\hline & $\mathrm{T} 2$ & 17.28 & $24.78 \mathrm{a}$ & $7.50 \mathrm{a}$ & $59.50 \mathrm{a}$ & $677.6 \mathrm{a}$ & $11.39 \mathrm{a}$ \\
\hline & T3 & 17.57 & $25.78 \mathrm{a}$ & $8.21 \mathrm{a}$ & $65.19 a$ & $754.7 \mathrm{a}$ & $11.58 \mathrm{a}$ \\
\hline & SEM & 0.65 & 0.78 & 0.52 & 4.15 & 31.12 & 1.49 \\
\hline & P-value & 0.9552 & 0.0043 & $<.0001$ & $<.0001$ & 0.001 & 0.0022 \\
\hline \multirow[t]{4}{*}{ Mean } & Afar & 18.26 & $25.62 \mathrm{a}$ & 7.36 & 58.44 & 719.1a & 12.3 \\
\hline & BHO & 17.41 & $24.06 \mathrm{~b}$ & 6.64 & 52.73 & $671.7 \mathrm{~b}$ & 12.74 \\
\hline & sem & 0.33 & 0.42 & 0.33 & 2.69 & 14.72 & 1.42 \\
\hline & $\mathrm{p}$-value & 0.0871 & 0.0138 & 0.1455 & 0.1455 & 0.025 & 0.7128 \\
\hline
\end{tabular}

Where, Means in the same column with different letters are statistically different $(\mathrm{p}<0.05)$; sem $=$ standard error of mean; LWC $=$ Live Weight Change;

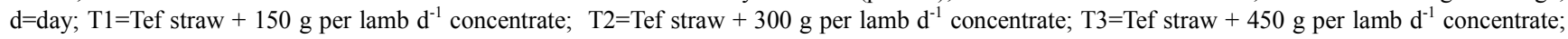
$\mathrm{BHO}=$ Blackhead ogaden lambs

\subsection{Carcass Parameters}

Results of carcass analysis are shown in Table 5. Disregarding breed difference, an increase in the level of concentrate improved SW ( $p=0.0003)$ of lambs by about $29 \%(19.5$ vs. $25.2 \mathrm{~kg})$, HCW $(\mathrm{p}<.0001)$ by $50 \%(7.6 v s$. $11.4 \mathrm{~kg})$, DP $(\mathrm{p}<.0001)$ by $16.8 \%(38.7 v s .45 .2 \mathrm{~kg})$ and lean-to-bone ratio by $47.4 \%\left(\begin{array}{lll}1.9 & \text { vs. } & 2.8\end{array}\right)$. Increasing 
concentrate feeding in Afar lambs increased SW from 20.7 to $26.2 \mathrm{~kg}$, HCW from 8.5 to $12 \mathrm{~kg}$, DP from 41 to 45.8 and LFR from 2.2 to 2.4. Moreover, higher level of concentrate increased the SW, HCW and DP in both breeds. Similarly, higher concentrate feeding increased HCW and DP of Afar lambs [9], whereas, increased $\mathrm{SW}$ and $\mathrm{HCW}$, but unimproved DP were reported for growing Afar lambs supplemented up to $350 \mathrm{~g} \mathrm{~d}^{-1}$ of wheat bran, noug seed (Guizotia abyssinica) cake and sesame seed cake mixture [12]. Also, it was [13] reported that improved SW, but no change in HCW and DP of Washera lambs fed urea treated rice straw and supplemented up to $400 \mathrm{~g} \mathrm{~d}^{-1}$ concentrate. In present study, higher concentrate level did not affect LFR in overall lambs and in BHO lambs, but increased $(p<0.05)$ LFR in Afar lambs. However, increasing the slaughter weight of BHO lambs from 18.3 (T1) to $24.1 \mathrm{~kg}$ (T3) changed LFR from 2.1 to 1.6 indicating favored fat tissue accretion. Diet had a significant effect $(p=0.0173)$ on lean-tobone ratio of lambs. In general, the response of Afar lambs to SW, HCW, DP, LFR and LBR was higher than that observed for BHO lambs. The observed increase in SW, DP and HCW upon increasing concentrate feeding suggest an increase in the available nutrient for absorption and/or improved feed utilization efficiency. Supporting the present work, increasing concentrate portion of a ration have been reported to improve the carcass traits of lambs [14-16].

Table 5. Carcass parameters of lambs fed test diets

\begin{tabular}{|c|c|c|c|c|c|c|}
\hline & Treat & SW & HCW & DP & LFR & LBR \\
\hline \multirow{4}{*}{ Diet } & $\mathrm{T} 1$ & $19.5 \mathrm{~b}$ & $7.6 \mathrm{~b}$ & $38.7 \mathrm{~b}$ & 2.2 & $1.9 \mathrm{~b}$ \\
\hline & $\mathrm{T} 2$ & $24.0 \mathrm{a}$ & $10.7 \mathrm{a}$ & $44.4 \mathrm{a}$ & 1.7 & $2.8 \mathrm{a}$ \\
\hline & $\mathrm{T} 3$ & $25.2 \mathrm{a}$ & $11.4 \mathrm{a}$ & $45.2 \mathrm{a}$ & 2.0 & $2.7 \mathrm{a}$ \\
\hline & sem & 0.71 & 0.34 & 0.69 & 2.00 & 0.20 \\
\hline \multirow{4}{*}{$\begin{array}{l}\text { Afar } \\
\text { lambs }\end{array}$} & $\mathrm{T} 1$ & $20.7 b$ & $8.5 \mathrm{~b}$ & $40.9 b$ & $2.2 \mathrm{ab}$ & 1.9 \\
\hline & $\mathrm{T} 2$ & $24.9 \mathrm{a}$ & $11.5 \mathrm{a}$ & $46.0 \mathrm{a}$ & $1.6 \mathrm{~b}$ & 3.0 \\
\hline & $\mathrm{T} 3$ & $26.2 \mathrm{a}$ & $12.0 \mathrm{a}$ & $45.8 \mathrm{a}$ & $2.4 \mathrm{a}$ & 2.7 \\
\hline & sem & 1.06 & 0.49 & 0.53 & 0.20 & 0.35 \\
\hline \multirow{4}{*}{$\begin{array}{l}\text { BHO } \\
\text { lambs }\end{array}$} & $\mathrm{T} 1$ & $18.3 b$ & $6.7 \mathrm{~b}$ & $36.4 b$ & 2.1 & $1.9 \mathrm{~b}$ \\
\hline & $\mathrm{T} 2$ & $23.1 \mathrm{a}$ & $9.9 \mathrm{a}$ & $42.8 \mathrm{a}$ & 1.8 & $2.6 \mathrm{a}$ \\
\hline & $\mathrm{T} 3$ & $24.1 \mathrm{a}$ & $10.8 \mathrm{a}$ & $44.7 \mathrm{a}$ & 1.6 & $2.7 \mathrm{a}$ \\
\hline & SEM & 0.95 & 0.48 & 1.27 & 0.21 & 0.20 \\
\hline \multirow{2}{*}{ Mean } & Afar & $23.9 \mathrm{a}$ & $10.6 \mathrm{a}$ & $44.2 \mathrm{a}$ & 2.1 & 2.5 \\
\hline & $\mathrm{BHO}$ & $21.8 b$ & $9.1 \mathrm{~b}$ & $41.3 b$ & 1.9 & 2.4 \\
\hline \multirow{3}{*}{$\begin{array}{l}\mathrm{p}- \\
\text { value }\end{array}$} & Diet & 0.0003 & $<.0001$ & $<.0001$ & 0.1342 & 0.0173 \\
\hline & Breed & 0.0257 & 0.0023 & 0.0031 & 0.2605 & 0.6100 \\
\hline & $\begin{array}{l}\text { Diet } x \\
\text { Breed }\end{array}$ & 0.9696 & 0.8499 & 0.2543 & 0.0613 & 0.8074 \\
\hline
\end{tabular}

Where, Means in the same column with different letters are statistically different $(\mathrm{P}<0.05)$; sem =standard error of mean; $\mathrm{SW}=$ Slaughter weight $; \mathrm{HCW}=$ hot carcass weight; $\mathrm{DP}($ Dressing\% $)=(\mathrm{HCW} / \mathrm{SW}) * 100$; $\mathrm{LFR}=$ lean-to-fat ratio; $\mathrm{LBR}=$ lean-to-bone ratio; $\mathrm{T}=\mathrm{Tef}$ straw $+150 \mathrm{~g}$ per lamb $\mathrm{d}^{-1}$ concentrate; $\mathrm{T} 2=$ Tef straw $+300 \mathrm{~g}$ per lamb $\mathrm{d}^{-1}$ concentrate; $\mathrm{T} 3=\mathrm{Tef}$ straw $+450 \mathrm{~g} /$ lamb d $\mathrm{d}^{-1}$ concentrate.
Table 6. Cost-profit analysis of the diets fed to lambs (ETB/lamb)

\begin{tabular}{lllllll}
\multicolumn{1}{c}{ Aable 6. Cost-profit analysis of the diets fed to lambs (ETB/lamb) } \\
& \multicolumn{1}{c}{ A1 } & T2 & T3 & T1 & T2 & T3 \\
\hline Variables & $\mathrm{n}=8$ & $\mathrm{n}=8$ & $\mathrm{n}=8$ & $\mathrm{n}=8$ & $\mathrm{n}=8$ & $\mathrm{n}=7$ \\
Input costs & & & & & & \\
Straw & 83 & 75 & 72 & 77 & 70 & 60 \\
Concentrate & 37 & 75 & 112 & 37 & 75 & 111 \\
Feed cost & 121 & 150 & 183 & 114 & 144 & 171 \\
Lambs & 271 & 276 & 276 & 261 & 259 & 264 \\
Labour cost & 63 & 63 & 63 & 63 & 63 & 63 \\
Vet.service & 5 & 5 & 5 & 5 & 5 & 5 \\
Transport fee & 17 & 17 & 17 & 17 & 17 & 17 \\
Total cost (1) & 476 & 510 & 544 & 460 & 488 & 520 \\
Income variables & & & & & & \\
*Sale at export & 543 & 617 & 679 & 517 & 593 & 617 \\
abattoir(2) & & & & & & \\
Net return 1(2-1) & 67 & 107 & 135 & 58 & 105 & 97 \\
Net return over T1 & - & 40 & 68 & - & 47 & 40 \\
Sale at Gate(3) & 588 & 694 & 746 & 514 & 604 & 660 \\
Net return 2(3-1) & 112 & 184 & 203 & 54 & 116 & 140 \\
Net return over T1 & - & 72 & 91 & - & 62 & 86 \\
\hline
\end{tabular}

*estimated at 23 birr kg-1 $^{-1}$ live weight. Market values of feed ingredients $\left(\right.$ ETB $\left.\mathrm{kg}^{-1}\right)$ : Wheat bran=1.76; Wheat middling $=2$; Noug seed cake=3; Maize grain=2.30; Salt=0.90); ETB (Ethiopian birr), 18 ETB =1 USD; N= number of lambs.

\subsection{Cost-Benefit Analysis}

With increased level of concentrate, feed cost increased from 120 to 183 ETB in Afar lamb and from 114 to 171 ETB in BHO lambs (Table 6). The total cost of production (considering all variable costs) in Afar lamb elevated from 476 (T1) to 544 (T2) and from 460(T1) to 519(T2) ETB in BHO lamb, which was mainly contributed by high cost of concentrate and its increased consumption. The net return from sale of lambs at bargaining price of export abattoirs, was positive and increased with increasing concentrate level. Similarly, selling at local market indicated a positive net return per lamb, and increased along with increasing concentrate. This could be due to improved growth and body condition of lambs, favoring their sale values, which was well reflected in Afar lambs than in BHO lambs. Generally, the highest reduction in cost of production was achieved on days lambs attained minimum target weight for marketing. Under the present feeding regime, relatively Afar lambs appeared to grow faster than BHO lambs and profitable at lower cost of feeding.

\section{Conclusion}

Up-grading yearling Afar and BHO lambs to meet the export market demand was achieved with the present feeding regimes. Supplementation of up to 450 and $300 \mathrm{~g} \mathrm{~d}^{-}$ ${ }^{1}$ of concentrate containing $19.4 \% \mathrm{CP}$ and $11.28 \mathrm{MJ} \mathrm{ME} \mathrm{kg}^{-}$ ${ }^{1} \mathrm{DM}$ appeared optimal to finish yearling Afar and $\mathrm{BHO}$ lambs, respectively. This study has indicated that meat production in terms of live weight change and carcass yield from Afar and BHO lambs can be considerably improved with economic benefit at higher than lower concentrate supplementation. 


\section{Acknowledgement}

The author gratefully acknowledged Ethiopian Institute of Agricultural Research, Debre Zeit Research Center, for funding this research and facilitating purchase of inputs. The assistance rendered by technical assistants: Mr Solomon Abiy, Mrs Workiye Shibiru and Mrs Asrat Endale in handling experimental animals and collecting data is highly appreciated and acknowledged.

\section{References}

[1] CSA (Central Statistic Authority) of Ethiopia, Agricultural Sample Survey. 2010. Report on Livestock and Livestock Characteristics (Private Peasant Holdings). Vol. II, pp. 94.

[2] Hurissa, B. and J.Eshetu. 2003. Challenges and opportunities of livestock trade in Ethiopia. Challenges and opportunities of livestock marketing in Ethiopia. In: Yilma Jobre and Getachew Gebru.(eds), Proceedings of $10^{\text {th }}$ annual conference of the Ethiopian Society of Animal Production (ESAP) held in Addis Ababa, Ethiopia, August 22-24, 2002. ESAP, Addis Ababa, Ethiopia. pp. 1-14.

[3] Betsha, S. 2005. Supplementation of graded levels of peanut cake and wheat bran mixtures on nutrient utilization and carcass parameters of Somali goats. An MSc Thesis Presented to the School of Graduate Studies of Alemaya University of Agriculture, Alemaya, Ethiopia.75p.

[4] Bogale, S., S. Melaku and A.Yami. 2008a. Potential use of crop residues as livestock feed resources under conditions of smallholder farmers in Bale highlands of Ethiopia. Tropical and sub-tropical Agro-ecosystems, 8, 107-114.

[5] IAR (Institute of Agricultural Research), 1991. Strategic Planning for Livestock Research in the Institute of Agricultural Research (IAR), Addis Ababa, Ethiopia.

[6] AOAC (Association of Official Analytical Chemists), 1990. Official method of analysis. $15^{\text {th }}$ ed. AOAC Inc., Arlington, Virginia, USA. pp. 12-98.

[7] Van Soest. P.J., Robertson, J.B., Lewis, B.A, 1991. Methods for dietary fiber, neutral detergent fiber and non-starch polysaccharides in relation to animal nutrition. J.Dairy Sci. 74,
3583-3597.

[8] SAS(Statistical Analysis System).2003. SAS Institute. Inc., Cary, NC, USA.

[9] Gala, E.S.E., K. Awugichew, B. Kebede, G. Yohannes and P.B. O'Donovan, 1979a. A study on fattening Ethiopian sheep: I. Performance of highland lambs under feedlot Conditions. Eth. J. of Agri.Sci. 1:93:98.

[10] Akalu, B. and E.S.E. Galal, 1981. Comparison between fattening ability of Adal and Black head Somali sheep. Animal Production Bulletin no. 14 (IAR) Addis Ababa, Ethiopia.

[11] Estifanos, A. and S. Melaku. 2009. Supplementation of graded level of wheat bran to intact and castrated Afar sheep fed urea treated tef straw: Effect on feed intake, digestibility, body weight and carcass characteristics. East African Journal of Sci.vol.3 no.1, 2009

[12] Hagos, T. and S. Melaku. 2009. Feed intake, digestibility, body weight and carcass parameters of Afar rams fed tef (Eragrostis tef) straw supplemented with graded levels of concentrate mix. Tropical Animal Health and Production. 41 599-606.

[13] Hailu, A., S. Melaku, B.Tamir and A.Tasew 2011. Body weight and carcass characteristics of Washera sheep fed urea treated rice straw supplemented with graded levels of concentratemixiture.2011. http:www-.Irrd.org/Irrd 23/8/cont2308.htm

[14] Papi N., Mostafa-Tehrania, A., Amanlou, H., Memarian, M. 2011. Effects of dietary forage-to-concentrate ratios on performance and carcass characteristics of growing fattailed lambs. Animal Feed Science and Technology 163: 9398 .

[15] Singh, N.P., Sankhyan, S.K., Prasad, S.S. 2004.Effect of supplementary concentrate on growth and carcass characteristics in crossbred sheep of dual purpose.Indian $J$. Anim. Sci. 74, 878-881.

[16] Mahgoub, O., Lu, C.D., R.J. Early, 2000.Effects of dietary energy density on feed intake, body weight gain and carcass chemical composition of Omani growing lambs. Small Rumin. Res. 37, 35-42. 